\title{
The novel microtubule-interfering agent TZT- 1027 enhances the anticancer effect of radiation in vitro and in vivo
}

\author{
Y Akashi', I Okamoto*,', M Suzuki², K Tamura ${ }^{3}$, T Iwasa', S Hisada ${ }^{4}$, T Satoh', K Nakagawa', K Ono ${ }^{2}$ \\ and M Fukuoka'
}

'Department of Medical Oncology, Kinki University School of Medicine, 377-2 Ohno-higashi, Osaka-Sayama, Osaka 589-85 I I, Japan; ${ }^{2}$ Radiation Oncology Research Laboratory, Research Reactor Institute, Kyoto University, 2- 1010 Asashiro-nishi, Kumatori-cho, Sennan-gun, Osaka 590-0494, Japan; ${ }^{3}$ Department of Medical Oncology, Kinki University School of Medicine, Nara Hospital, 1248-I Otodacho, Ikoma,Nara 630-0293, Japan; ${ }^{4}$ Asuka

Pharmaceutical Co. Ltd, 1604 Shimosakunobe, Takatu-ku, Kawasaki 21 3-8522, Japan

\begin{abstract}
TZT-I027 is a novel anticancer agent that inhibits microtubule polymerisation and manifests potent antitumour activity in preclinical models. We have examined the effect of TZT-I027 on cell cycle progression as well as the anticancer activity of this drug both in vitro and in vivo. With the use of tsFT2 10 cells, which express a temperature-sensitive mutant of Cdc2, we found that TZT- I027 arrests cell cycle progression in mitosis, the phase of the cell cycle most sensitive to radiation. A clonogenic assay indeed revealed that $\mathrm{TZT}$ 1027 increased the sensitivity of $\mathrm{H} 460$ cells to $\gamma$-radiation, with a dose enhancement factor of 1 .2. Furthermore, TZT- 027 increased the radiosensitivity of $\mathrm{H} 460$ and $\mathrm{A} 549$ cells in nude mice, as revealed by a marked delay in tumour growth and an enhancement factor of 3.0 and 2.2, respectively. TZT- 1027 also potentiated the induction of apoptosis in $\mathrm{H} 460$ cells by radiation both in vitro and in vivo. Histological evaluation of $\mathrm{H} 460$ tumours revealed that TZT- 1027 induced morphological damage to the vascular endothelium followed by extensive central tumour necrosis. Our results thus suggest that TZT-1027 enhances the antitumour effect of ionising radiation, and that this action is attributable in part to potentiation of apoptosis induction and to an antivascular effect. Combined treatment with TZT-I027 and radiation therefore warrants investigation in clinical trials as a potential anticancer strategy.

British Journal of Cancer (2007) 96, I532-1539. doi:I0.1038/sj.bjc.6603769 www.bjcancer.com
\end{abstract}

Published online I May 2007

(C) 2007 Cancer Research UK

Keywords: TZT-1027; radiosensitisation; microtubule; mitotic arrest; apoptosis; antivascular effect

The combination of modalities of cancer treatment offers improvements in the survival of cancer patients compared with individual therapeutic approaches. Such therapeutic benefit has been achieved with combinations of chemo- and radiotherapy in a variety of cancers. The cytotoxicity of most chemotherapeutic agents as well as that of radiation is highly dependent on the phase of the cell cycle. Although various types of anticancer drugs are able to arrest cells at specific cell cycle checkpoints, the ability of antimicrotubule agents to block cell cycle progression in $\mathrm{G}_{2}-\mathrm{M}$ phase is the biological basis for combination of these agents with radiation (Pawlik and Keyomarsi, 2004). Microtubule-interfering agents have been shown to increase the radiosensitivity of tumour cells in preclinical and clinical studies (Liebmann et al, 1994; Choy et al, 1995; Edelstein et al, 1996; Vokes et al, 1996; Kim et al, 2001, 2003; Hofstetter et al, 2005; Simoens et al, 2006).

TZT-1027 (Soblidotin), a novel microtubule-interfering agent synthesised from dolastatin 10 (Figure 1), exhibits greater antitumour activities and a reduced toxicity compared with its

*Correspondence: Dr I Okamoto;

E-mail: okamoto@dotd.med.kindai.ac.jp

Revised 28 February 2007; accepted 2 April 2007; published online I May 2007 parent compound (Miyazaki et al, 1995). TZT-1027 inhibits microtubule assembly by binding to tubulin (Kobayashi et al, 1997; Natsume et al, 2000). In vitro, it inhibits the growth of various human cancer cells at low concentrations (Watanabe et al, 2000). In vivo, TZT-1027 also manifests a broad spectrum of activity against various murine tumours as well as human tumour xenografts, without inducing a pronounced reduction in body weight (Kobayashi et al, 1997; Watanabe et al, 2000, 2006a; Natsume et al, 2003, 2006). Furthermore, the drug exhibited a potent antivascular effect on existing vasculature in an advancedstage tumour model (Otani et al, 2000). TZT-1027 is currently undergoing clinical evaluation, with a reduction in tumour size and disease stabilisation having been observed in a subset of patients (Schoffski et al, 2004; de Jonge et al, 2005; Greystoke et al, 2006; Tamura et al, 2007).

Despite its demonstrated efficacy against solid tumours, the effects of TZT-1027 in combination with radiation have not been examined. As an initial step in determining the antitumour activity of TZT-1027 in combination with radiation, we investigated the effect of this agent on cell cycle progression in synchronised tsFT210 cells (Osada et al, 1997), which harbour a temperaturesensitive mutant of Cdc2. We found that TZT-1027 induces arrest of cells in mitosis, the phase of the cell cycle most sensitive to radiation. We then studied the radiosensitising properties of TZT1027 in vitro and in vivo with a human lung cancer model and elucidated the mechanism of radiosensitisation by this agent. 


\section{MATERIALS AND METHODS}

\section{Cell lines and reagents}

tsFT210 mouse mammary carcinoma cells, which express a temperature-sensitive mutant of $\mathrm{Cdc} 2$, were kindly provided by H Kakeya (Antibiotics Laboratory, Discovery Research Institute, RIKEN, Saitama, Japan) and were maintained under a humidified atmosphere of $5 \% \mathrm{CO}_{2}$ in air at $32.0^{\circ} \mathrm{C}$ in RPMI 1640 (Sigma, St Louis, MO, USA) supplemented with $10 \%$ foetal bovine serum and $1 \%$ penicillin-streptomycin. $\mathrm{H} 460$ human lung large cell carcinoma and A549 human lung adenocarcinoma cells were obtained from American Type Culture Collection (Manassas, VA, USA) and were maintained as for tsFT210 cells with the exception that the culture temperature was $37^{\circ} \mathrm{C}$. TZT-1027 (Figure 1) was provided by Daiichi Pharmaceutical Co. Ltd (Tokyo, Japan). Nocodazole and roscovitine were obtained from Sigma.

\section{Cell cycle analysis}

Cells were harvested, washed with phosphate-buffered saline (PBS), fixed with $70 \%$ methanol, washed again with PBS, and stained with propidium iodide $\left(0.05 \mathrm{mg} \mathrm{ml}^{-1}\right)$ in a solution containing $0.1 \%$ Triton X-100, $0.1 \mathrm{~mm}$ EDTA, and RNase A $\left(0.05 \mathrm{mg} \mathrm{ml}^{-1}\right)$. The stained cells $\left(\sim 1 \times 10^{6}\right)$ were then analysed for DNA content with a flow cytometer (FACScalibur; Becton Dickinson, San Jose, CA, USA).

\section{Measurement of mitotic index and apoptotic cells}

Cells were harvested, washed with PBS, fixed with methanol: acetic acid $(3: 1, v / v)$, washed again with PBS, and stained with $4^{\prime}, 6-$ diamidino-2-phenylindole (DAPI) $\left(0.5 \mu \mathrm{g} \mathrm{ml}^{-1}\right)$. The stained cells $\left(\sim 1 \times 10^{6}\right)$ were observed with a fluorescence microscope (IX71; Olympus, Tokyo, Japan). To determine the proportion of mitotic or apoptotic cells, we scored at least 300 cells in each of at least three randomly selected microscopic fields for each of three slides per sample. Cells with condensed chromosomes and no obvious nuclear membrane were regarded as mitotic cells, and the mitotic index was calculated as the percentage of mitotic cells among total viable cells. Cells with fragmented and uniformly condensed nuclei were regarded as apoptotic cells.

\section{Clonogenic assay}

Exponentially growing $\mathrm{H} 460$ cells in $25-\mathrm{cm}^{2}$ flasks were harvested by exposure to trypsin and counted. They were diluted serially to appropriate densities and plated in triplicate in $25-\mathrm{cm}^{2}$ flasks containing $10 \mathrm{ml}$ of medium. The cells were treated with $1 \mathrm{nM}$ TZT1027 or vehicle (dimethyl sulfoxide, or DMSO; final concentration, $0.1 \%$ ) for $24 \mathrm{~h}$ and then exposed to various doses of $\gamma$-radiation with a ${ }^{60} \mathrm{Co}$ irradiator at a rate of $\sim 0.82 \mathrm{~Gy} \mathrm{~min}^{-1}$ and at room temperature. The cells were then washed with PBS, cultured in drug-free medium for 10-14 days, fixed with methanol: acetic acid $(10: 1, v / v)$, and stained with crystal violet. Colonies containing $>50$ cells were counted. The surviving fraction was calculated as: (mean number of colonies)/(number of inoculated cells $\times$ plating efficiency). Plating efficiency was defined as the mean number of colonies divided by the number of inoculated cells for nonirradiated controls. The surviving fraction for combined treatment was corrected by that for TZT-1027 treatment alone. The dose enhancement factor (DEF) was calculated as the dose (Gy) of radiation that yielded a surviving fraction of 0.1 for vehicle-treated cells divided by that for TZT-1027-treated cells (after correction for drug toxicity).

\section{In vivo antitumour activity of TZT-1027 with or without radiation}

All animal studies were performed in accordance with the Recommendations for Handling of Laboratory Animals for Biomedical Research, compiled by the Committee on Safety and Ethical Handling Regulations for Laboratory Animal Experiments, Kyoto University. The ethical guidelines followed meet the requirements of the UKCCCR guidelines (Workman et al, 1998). Tumour cells $\left(2 \times 10^{6}\right)$ were injected subcutaneously into the right hind leg of 7-week-old female athymic nude mice. Tumour volume was determined from caliper measurement of tumour length $(L)$ and width $(W)$ according to the formula $L W^{2} / 2$. Treatment was initiated when tumours in each group achieved an average volume of $\sim 200-250 \mathrm{~mm}^{3}$. Treatment groups consisted of control, TZT1027 alone, radiation alone, and the combination of TZT-1027 and radiation. Each treatment group contained six to eight mice. TZT1027 was administered intravenously in a single dose of $0.5 \mathrm{mg} \mathrm{kg}^{-1}$ of body weight; mice in the control and radiation-alone groups were injected with vehicle (physiological saline). Tumours in the leg were exposed to $10 \mathrm{~Gy}$ of $\gamma$-radiation with a ${ }^{60} \mathrm{Co}$ irradiator at a rate of $\sim 0.32 \mathrm{~Gy} \mathrm{~min}^{-1}$ immediately after drug treatment. Growth delay (GD) was calculated as the time for treated tumours to achieve an average volume of $500 \mathrm{~mm}^{3}$ minus the time for control tumours to reach $500 \mathrm{~mm}^{3}$. The enhancement factor was then determined as: $\left(\mathrm{GD}_{\text {combination }}-\mathrm{GD}_{\mathrm{TZT}-1027}\right) /\left(\mathrm{GD}_{\text {radiation }}\right)$.

\section{TUNEL staining}

Mice were killed 14 days after treatment initiation and the tumours were removed and preserved in $10 \%$ paraformaldehyde. Apoptosis in tumour sections was determined by the terminal deoxynucleotidyl transferase-mediated dUTP-biotin nick-end labelling (TUNEL) assay with the use of an apoptosis detection kit (Chemicon, Temecula, CA, USA). The number of apoptotic cells was counted in 10 separate microscopic fields $(\times 100)$ for three sections of each tumour of each group.

\section{Histological analysis}

A single dose of TZT-1027 (2.0 mg kg ${ }^{-1}$ ) or vehicle (physiological saline) was administered intravenously to mice when H460 tumours had achieved a volume of $\sim 400$ to $600 \mathrm{~mm}^{3}$. Tumour tissue was extirpated 4 or $24 \mathrm{~h}$ after drug administration, and half of the tissue was fixed in $10 \%$ buffered formalin, embedded in paraffin, sectioned, and stained with hematoxylin-eosin. The other half of the tumour tissue was fixed for $12-48 \mathrm{~h}$ in zinc fixative<smiles>CC[C@H](C)[C@H]([C@@H](CC(=O)N1CCC[C@H]1[C@H](OC)[C@@H](C)C(=O)NCCc1ccccc1)OC)N(C)C(=O)[C@@H](NC(=O)[C@@H](C(C)C)N(C)C)C(C)C</smiles>

Figure I Chemical structure of TZT-I027. 
(BD Biosciences, San Jose, CA, USA), embedded in paraffin, sectioned, and immunostained for CD31. Endogenous peroxidase activity was blocked by incubation of the latter sections for $20 \mathrm{~min}$ with $0.3 \% \mathrm{H}_{2} \mathrm{O}_{2}$ in methanol, and nonspecific sites were blocked with antibody diluent (Dako Japan, Kyoto, Japan). Sections were then incubated overnight at $4^{\circ} \mathrm{C}$ with a $1: 50$ dilution of a rat monoclonal antibody to mouse CD31 (BD Biosciences), washed with PBS, and processed with a Histfine Simple Stain PO (M) kit (Nichirei, Tokyo, Japan) for detection of immune complexes. Sections were counterstained with Mayer's hematoxylin, covered with a coverslip with the use of a permanent mounting medium, and examined with a light microscope (CX41; Olympus, Tokyo, Japan).

\section{Statistical analysis}

Data are presented as means \pm s.d. or s.e. and were compared by the unpaired Student's $t$-test. A $P$ value of $<0.05$ was considered statistically significant.

\section{RESULTS}

Induction of cell cycle arrest at $M$ phase but not at $G_{1}-S$ in tsFT210 cells by TZT-1027

To examine the effect of TZT-1027 on cell cycle progression, we performed flow cytometric analysis of tsFT210 cells, which express a temperature-sensitive mutant of $\mathrm{Cdc} 2$. These mammary carcinoma cells exhibit a normal cell cycle distribution when incubated at the permissive temperature of $32.0^{\circ} \mathrm{C}$, but they arrest at $\mathrm{G}_{2}$ phase as a result of $\mathrm{Cdc} 2$ inactivation when incubated at the nonpermissive temperature of $39.4^{\circ} \mathrm{C}$ (Figure $2 \mathrm{~A}$ and $\mathrm{B}$ ). $\mathrm{We}$ synchronised tsFT210 cells at $\mathrm{G}_{2}$ phase by incubation at $39.4^{\circ} \mathrm{C}$ for $17 \mathrm{~h}$ and then cultured them at $32.0^{\circ} \mathrm{C}$ for $6 \mathrm{~h}$ in the presence of nocodazole (an inhibitor of microtubule polymerisation), TZT1027 , or vehicle (DMSO). In the presence of vehicle alone, the number of cells in $G_{2}$ phase decreased markedly and there was a corresponding increase in the number of cells in $G_{1}$ phase, indicative of re-entry of cells into the cell cycle (Figure 2C). In contrast, treatment with nocodazole or TZT-1027 prevented the cells from passing through $\mathrm{G}_{2}-\mathrm{M}$ phase (Figure $2 \mathrm{D}$ and $\mathrm{E}$ ). Given that flow cytometric analysis did not distinguish between cells in $M$ phase and those in $G_{2}$ phase, we determined the mitotic index of cells by DAPI staining and fluorescence microscopy. Most of the cells released from temperature-induced arrest in the presence of nocodazole manifested condensed chromosomes without a nuclear membrane, yielding a mitotic index of $93 \%$; most of the cells had thus arrested in mitosis (Figure 2D). Most of the cells released from temperature-induced arrest in the presence of TZT-1027 showed similar mitotic figures, yielding a mitotic index of $85 \%$ (Figure 2E) and demonstrating that TZT-1027 also inhibits cell cycle progression at mitosis.

We next examined whether TZT-1027 affects the $\mathrm{G}_{1}-\mathrm{S}$ transition. We arrested tsFT210 cells at $\mathrm{G}_{2}$ phase by incubation at $39.4^{\circ} \mathrm{C}$, released the cells into $G_{1}$ phase by shifting to the permissive temperature for $6 \mathrm{~h}$, and then incubated them for an additional $6 \mathrm{~h}$ in the presence of roscovitine (an inhibitor of CDK2 that prevents cell cycle progression at $\mathrm{G}_{1}$ phase), TZT-1027, or vehicle (Figure 3 ). The cells incubated with vehicle passed through $G_{1}$ phase and yielded a broad S-phase peak (Figure 3D), whereas those treated with roscovitine did not pass through $G_{1}$ phase (Figure $3 E$ ). In contrast, TZT-1027 had no effect on passage of the synchronised tsFT210 cells through the $\mathrm{G}_{1}-\mathrm{S}$ transition (Figure $3 \mathrm{~F}$ ). Together,
A

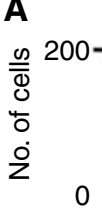

C

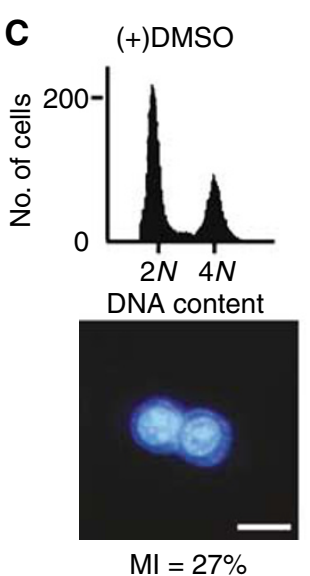

$\mathrm{MI}=27 \%$

NA content

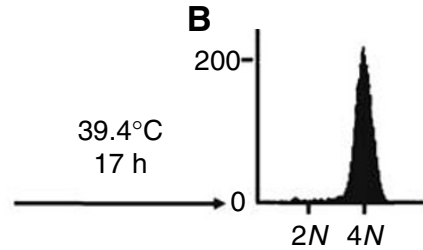

$32^{\circ} \mathrm{C}, 6 \mathrm{~h}$

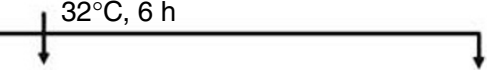

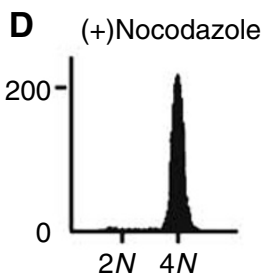

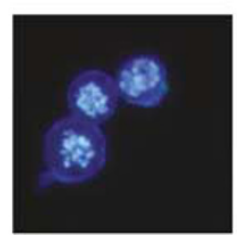

$\mathrm{Ml}=93 \%$
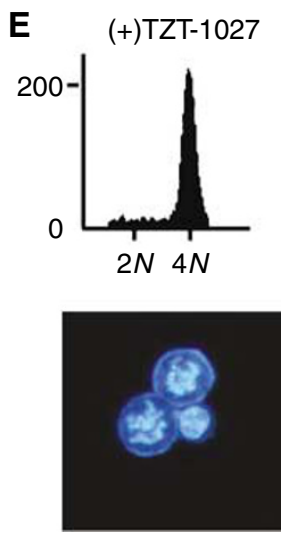

$\mathrm{MI}=85 \%$

Figure 2 Inhibition of tsFT2 10 cell cycle progression through $\mathrm{G}_{2}-\mathrm{M}$ by TZT- I027. Cells were cultured at the permissive temperature of $32.0^{\circ} \mathrm{C}(\mathbf{A})$ and then incubated for $17 \mathrm{~h}$ at the nonpermissive temperature of $39.4^{\circ} \mathrm{C}(\mathbf{B})$. They were subsequently released from $\mathrm{G}_{2}$ arrest by incubation at $32.0^{\circ} \mathrm{C}$ for $6 \mathrm{~h}$ in the presence of DMSO (C), I $\mu \mathrm{M}$ nocodazole (D), or $2 \mathrm{nM}$ TZT-I 027 (E). At each stage of the protocol, cells were analysed for DNA content by staining with propidium iodide and flow cytometry. The $2 \mathrm{~N}$ and $4 \mathrm{~N}$ peaks indicate cells in $\mathrm{G}_{0}-\mathrm{G}_{1}$ and $\mathrm{G}_{2}-\mathrm{M}$ phases of the cell cycle, respectively. The cells were also stained with DAPI and examined by fluorescence microscopy after treatment with DMSO, nocodazole, or TZT-I027 (lower panels), and the mitotic index (MI) was determined; scale bar, $20 \mu \mathrm{m}$. Data are representative of at least three independent experiments. 
these results indicate that the effect of TZT-1027 on cell cycle progression is specific to $\mathrm{M}$ phase.

\section{Induction of cell cycle arrest at $M$ phase in asynchronous H460 cells by TZT-1027}

We next examined whether TZT-1027 induced mitotic arrest in asynchronous H460 human non-small cell lung cancer cells. Flow cytometric analysis revealed that treatment of H460 cells with TZT1027 for $24 \mathrm{~h}$ induced a threefold increase in the proportion of cells with a DNA content of $4 \mathrm{~N}$ compared with that apparent for
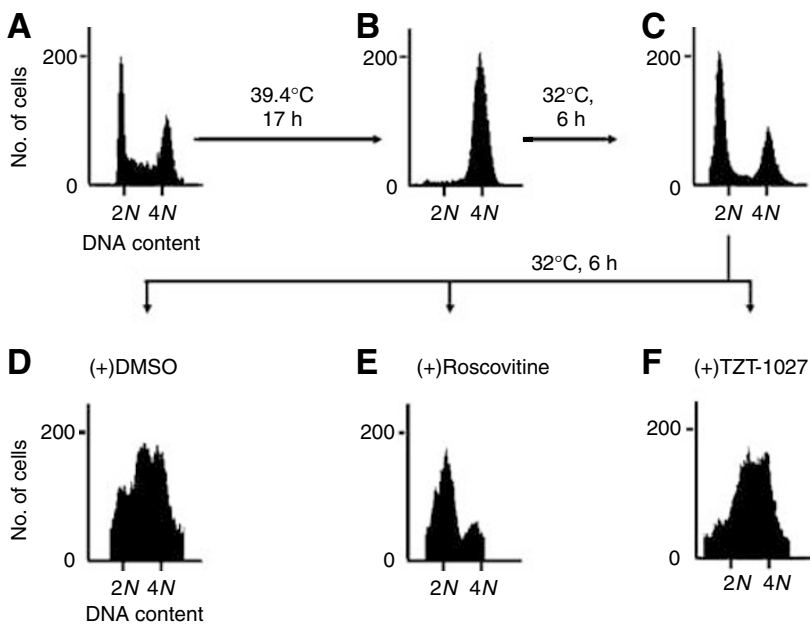

Figure 3 Lack of effect of TZT-I027 on tsFT2 I 0 cell cycle progression through $\mathrm{G}_{1}$-S. Exponentially growing tsFT2 I 0 cells $(\mathbf{A})$ were arrested in $\mathrm{G}_{2}$ phase by incubation for $17 \mathrm{~h}$ at $39.4^{\circ} \mathrm{C}(\mathbf{B})$. The cells were incubated at $32.0^{\circ} \mathrm{C}$ first for $6 \mathrm{~h}$ to allow progression to $\mathrm{G}_{1}$ phase $(\mathbf{C})$ and then for an additional $6 \mathrm{~h}$ in the presence of DMSO (D), $50 \mu \mathrm{M}$ roscovitine $(\mathbf{E})$, or $2 \mathrm{nM}$ TZT-I 027 (F). At each stage of the protocol, cells were analysed for DNA content by flow cytometry. Data are representative of at least three independent experiments. vehicle-treated cells (29.1 vs 8.7\%) (Figure 4A and B). Furthermore, DAPI staining revealed that TZT-1027 induced a significant increase in the mitotic index of H460 cells compared with that for the control cells (23.3 vs 4.6\%) (Figure $4 \mathrm{C}$ and D), indicating that most of the TZT-1027-treated cells with a DNA content of $4 \mathrm{~N}$ were arrested in $M$ phase rather than in $G_{2}$ phase. These observations thus showed that TZT-1027 also induced mitotic arrest in asynchronous $\mathrm{H} 460$ cells.

\section{Radiosensitisation of $\mathrm{H} 460$ cells by TZT-1027 in vitro}

Cells in $\mathrm{M}$ phase are more sensitive to radiation than are those in other phases of the cell cycle. Given that exposure of H460 cells to TZT-1027-induced mitotic arrest, we next examined whether this agent might sensitise $\mathrm{H} 460$ cells to $\gamma$-radiation with the use of a clonogenic assay. H460 cells were incubated for $24 \mathrm{~h}$ with $1 \mathrm{~nm}$ TZT-1027 or vehicle (DMSO) and then exposed to various doses $(0,2,4$, or $6 \mathrm{~Gy})$ of $\gamma$-radiation. The cells were then allowed to form colonies in drug-free medium for 10-14 days. Survival curves revealed that TZT-1027 increased the radiosensitivity of $\mathrm{H} 460$ cells, with a DEF of 1.2 (Figure 5A).

To determine whether radiosensitisation by TZT-1027 was reflected by an increase in the proportion of apoptotic cells, we exposed H460 cells to $1 \mathrm{~nm}$ TZT-1027 or vehicle for $24 \mathrm{~h}$, treated the cells with various doses $(0,2,4$, or $6 \mathrm{~Gy})$ of radiation, and then incubated them in drug-free medium for an additional $24 \mathrm{~h}$ before quantification of apoptosis. Combined treatment with TZT-1027 and 4 or $6 \mathrm{~Gy}$ of radiation resulted in a significant increase in the number of apoptotic cells compared with the sum of the values for treatment with drug alone or radiation alone (Figure 5B). TZT-1027 thus promoted radiation-induced apoptosis in $\mathrm{H} 460$ cells.

\section{Radiosensitisation of $\mathrm{H} 460$ cells and A549 cells by TZT-1027 in vivo}

To determine whether the TZT-1027-induced increase in the radiosensitivity of tumour cells observed in vitro might also be apparent in vivo, we injected H460 cells or A549 human lung
A

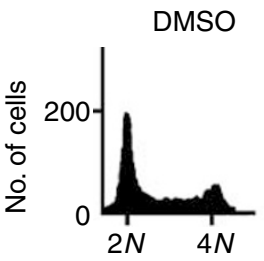

DNA content

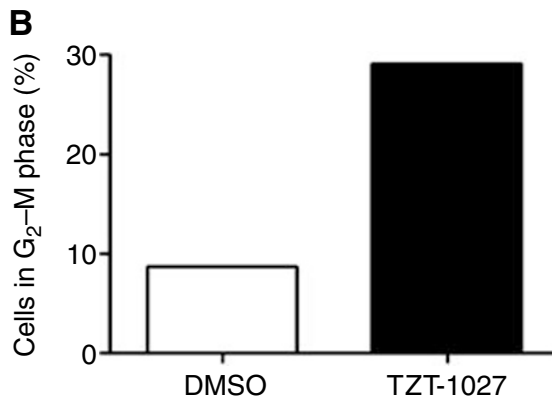

C

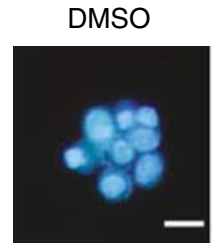

TZT-1027
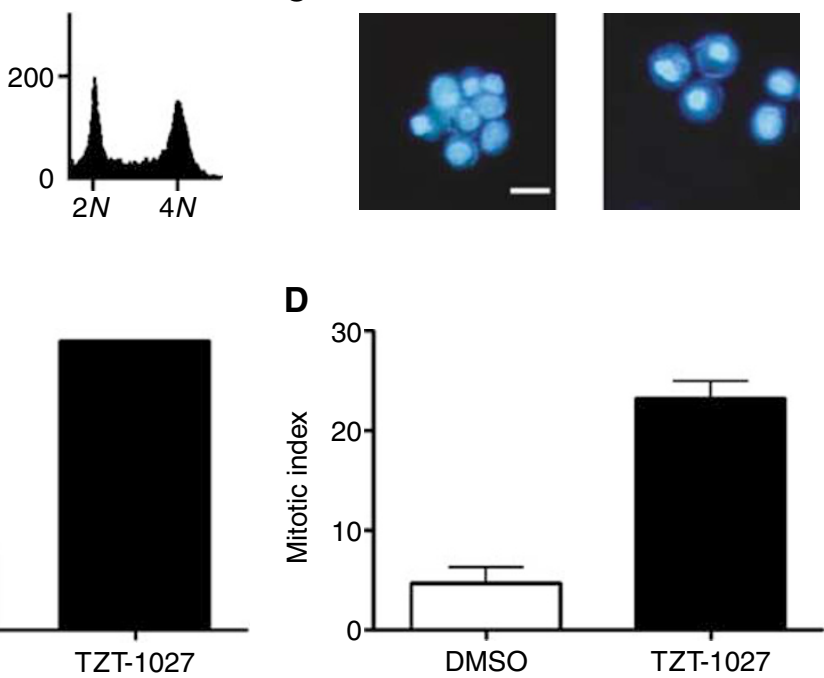

Figure 4 Induction of cell cycle arrest at M phase in H460 cells by TZT- I027. H460 cells were incubated in the presence of I nM TZT- I027 or vehicle (DMSO) for $24 \mathrm{~h}$, after which DNA content was measured by flow cytometry $(\mathbf{A})$ and the fraction of cells in $\mathrm{G}_{2}-\mathrm{M}$ phase was determined (B). The cells were also stained with DAPI and examined by fluorescence microscopy $(\mathbf{C})$ and the mitotic index was determined (D). Data in (A) through (C) are representative of at least three independent experiments; data in (D) are means \pm s.d. of values from three independent experiments. Scale bar in (C), $20 \mu \mathrm{m}$. 


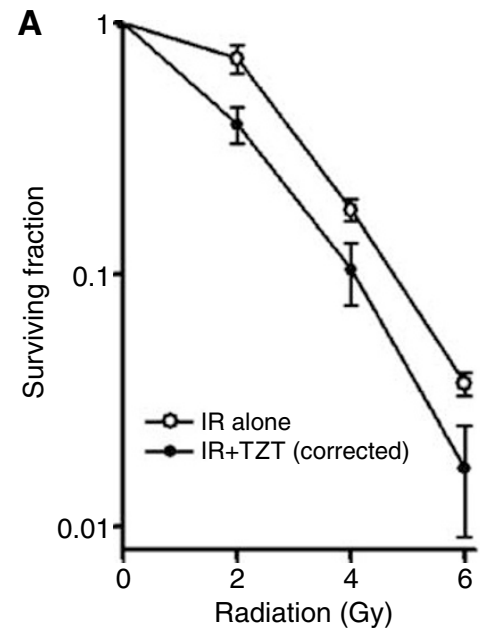

B

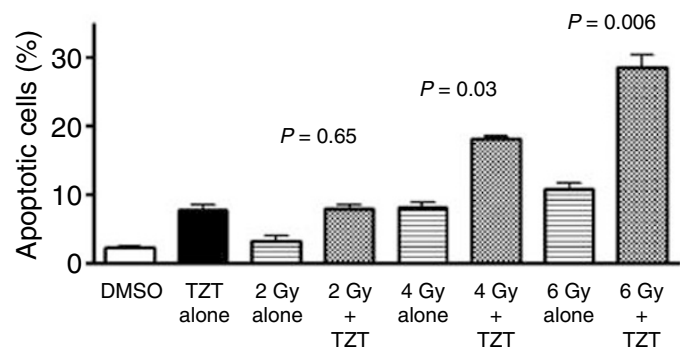

Figure 5 Sensitisation of $\mathrm{H} 460$ cells to $\gamma$-radiation by TZT-I027 in vitro. (A) Clonogenic assay. Cells were incubated with I nM TZT-I027 or vehicle (DMSO) for $24 \mathrm{~h}$, exposed to the indicated doses of $\gamma$-radiation, and then incubated in drug-free medium for 10 - 14 days for determination of colonyforming ability. Survival curves were generated after correction of colony formation observed for combined treatment with ionising radiation (IR) and TZT1027 by that apparent for treatment with TZT- 1027 alone. (B) Assay of apoptosis. Cells were incubated with I nM TZT-I 027 or vehicle (DMSO) for 24 h, exposed to various doses (0, 2, 4, or $6 \mathrm{~Gy})$ of $\gamma$-radiation, and then incubated for $24 \mathrm{~h}$ in drug-free medium. Cells were then fixed and stained with DAPI for determination of the proportion of apoptotic cells by fluorescence microscopy. Data in $(\mathbf{A})$ and $(\mathbf{B})$ are means \pm s.d. of values from three independent experiments. $P$ values in (B) are for comparison of the value for combined treatment with TZT-I 027 and radiation vs the sum of the corresponding values for each treatment alone, after correction of all data by the control (DMSO) value.

adenocarcinoma cells into nude mice in order to elicit the formation of solid tumours. The mice were then treated with TZT-1027, radiation, or both modalities. Treatment with TZT-1027 alone (single dose of $0.5 \mathrm{mg} \mathrm{kg}^{-1}$ ) or with radiation alone (single dose of $10 \mathrm{~Gy}$ ) resulted in relatively small inhibitory effects on tumour growth, whereas combined treatment with both TZT-1027 and radiation exerted a markedly greater inhibitory effect (Figure $6 \mathrm{~A}$ and $\mathrm{B}$ ). The tumour GDs induced by treatment with TZT-1027 alone, radiation alone, or both TZT-1027 and radiation were 1.0, 2.6, and 8.8 days, respectively, for $\mathrm{H} 460$ cells and 1.4, 4.9, and 12.4 days, respectively, for A549 cells (Table 1). The enhancement factor for the effect of TZT-1027 on the efficacy of radiation was 3.0 for $\mathrm{H} 460$ cells and 2.2 for A549 cells, revealing the effect to be greater than additive. No pronounced tissue damage or toxicities such as diarrhoea or weight loss of $>10 \%$ were observed in mice in any of the four treatment groups (Table 2).

We examined the effects of the treatment protocols on apoptosis in H460 tumours by TUNEL staining of tumour sections. Quantification of the number of apoptotic cells revealed that the combined treatment with radiation and TZT-1027 induced a significant increase in this parameter compared with treatment with radiation or TZT-1027 alone (Figure 6C).

\section{Histological appearance of H460 tumours after administration of TZT-1027}

Finally, we examined whether an effect of TZT-1027 on tumour vasculature might contribute to the antitumour activity of this drug in vivo. Mice harbouring H460 tumours were injected with TZT-1027, and the tumours were excised 4 or $24 \mathrm{~h}$ thereafter and examined by hematoxylin-eosin staining (Figure 7A-C) or by immunostaining for the endothelial cell marker CD31 (Figure 7D and E). Tumour capillaries appeared congested, with thrombus formation, and showed a loss of endothelial cells $4 \mathrm{~h}$ after administration of TZT-1027 (Figure 7B and E), whereas vessels within viable areas of control tumours were generally not congested and showed an intact normal endothelium (Figure 7A and D). The effects of TZT-1027 on the tumour vasculature appeared selective, given that neither loss of CD31 staining nor vessel congestion was apparent in the vasculature of surrounding normal tissue after drug treatment (Figure 7E). Extensive necrosis was apparent at the tumour core, with a characteristic thin rim of viable tumour cells remaining at the periphery, $24 \mathrm{~h}$ after TZT1027 administration (Figure 7C). These results were thus indicative of a characteristic antivascular effect of TZT-1027 in the H460 tumour model.

\section{DISCUSSION}

TZT-1027 is a novel antitumour agent that inhibits microtubule polymerisation and exhibits potent antitumour activity in preclinical models (Miyazaki et al, 1995; Kobayashi et al, 1997; Natsume et al, 2000, 2003, 2006; Otani et al, 2000; Watanabe et al, $2000,2006 a)$. We investigated the effect of TZT-1027 on cell cycle progression with the use of tsFT210 cells, which can be synchronised in $\mathrm{G}_{2}$ phase by incubation at $39.4^{\circ} \mathrm{C}$ and consequent inactivation of Cdc2 (Osada et al, 1997; Tamura et al, 1999). The use of these cells allows cell synchronisation without the need for agents that prevent DNA synthesis (such as hydroxyurea or thymidine) or that inhibit formation of the mitotic spindle (such as nocodazole). Although such agents halt cell cycle progression in specific phases of the cycle, they are also toxic and kill a proportion of the treated cells. The tsFT210 cell system is thus suited to sensitive analysis of the effects of new compounds on cell cycle progression without loss of cell viability. We have now shown that tsFT210 cells released from $\mathrm{G}_{2}$ arrest by incubation at $32.0^{\circ} \mathrm{C}$ failed to pass through $\mathrm{M}$ phase in the presence of TZT-1027. Although previous flow cytometric analysis of exponentially growing tumour cells revealed that TZT-1027 induced a marked increase in the proportion of cells in $\mathrm{G}_{2}-\mathrm{M}$ (Watanabe et al, 2000), it was uncertain whether the drug arrested cell cycle progression in $\mathrm{G}_{2}$ or in mitosis. Our morphological data now indicate that, similar to the effect of nocodazole, TZT-1027 arrested tsFT210 cells in M phase rather than in $G_{2}$, consistent with the mode of action of this new compound. Given that microtubules contribute to various cellular functions in addition to cell division, including intracellular transport and signal transduction (Mollinedo and Gajate, 

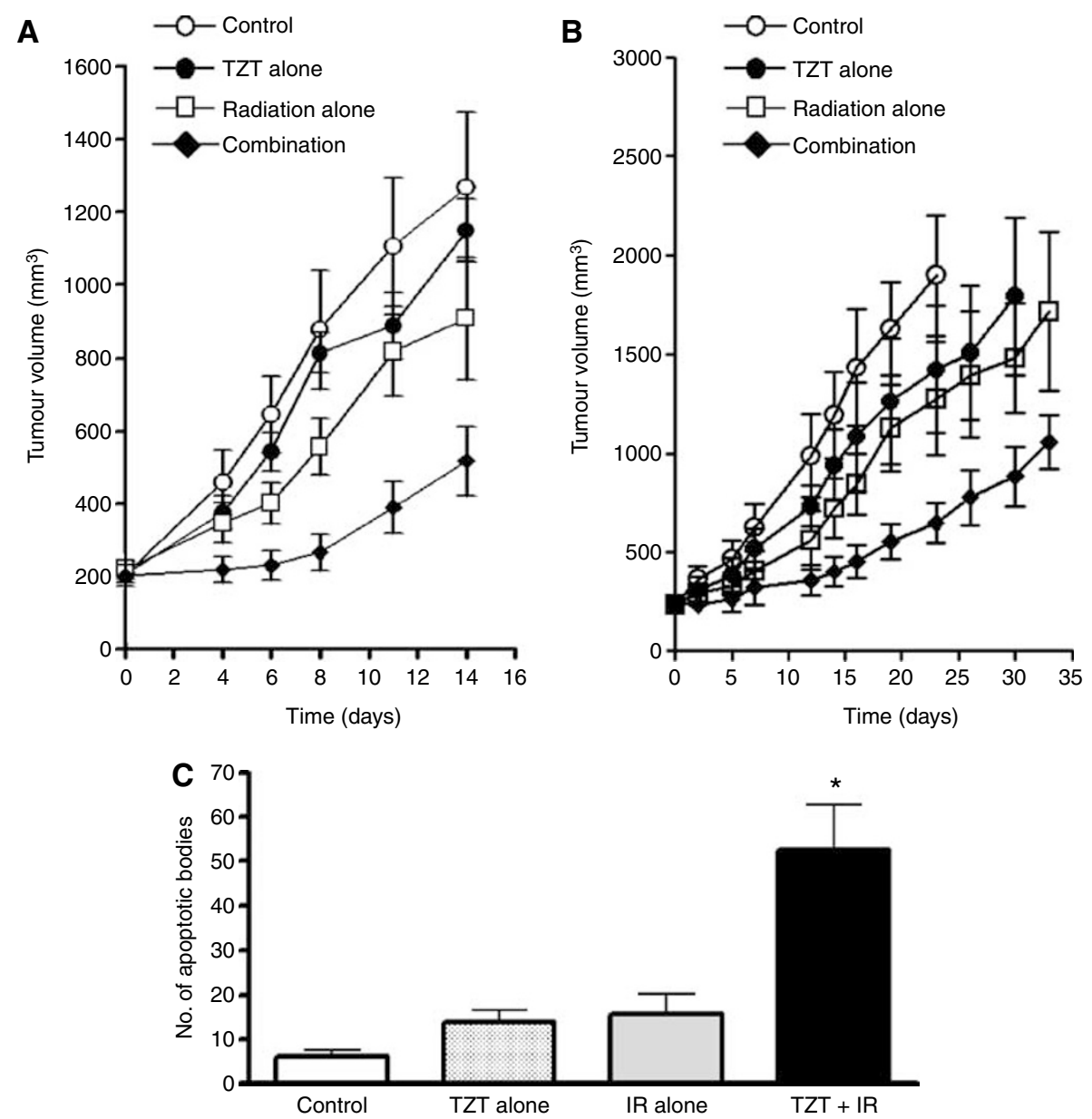

Figure 6 Sensitisation of $\mathrm{H} 460$ and A549 cells to $\gamma$-radiation by TZT-I027 in vivo. (A and B) Evaluation of tumour growth. Nude mice with H460 (A) or A549 (B) tumour xenografts $\left(\sim 200\right.$ to $\left.250 \mathrm{~mm}^{3}\right)$ were treated with a single intravenous dose of TZT- I $027\left(0.5 \mathrm{mg} \mathrm{kg}^{-1}\right)$, a single dose of $\gamma$-radiation ( I 0 Gy), or neither (control) or both modalities, and tumour volume was determined at the indicated times thereafter. Data are means \pm s.e. for six to eight mice per group. (C) Quantification of apoptotic cells in $\mathrm{H} 460$ tumour sections by TUNEL staining I 4 days after the initiation of treatment as in $(\mathbf{A})$. Data are means \pm s.d. $* P<0.05$ vs mice treated with TZT-I 027 alone or radiation alone.

Table I Tumour growth delay value

\begin{tabular}{|c|c|c|c|c|}
\hline \multirow[b]{2}{*}{ Treatment } & \multicolumn{2}{|c|}{$\mathrm{H} 460$} & \multicolumn{2}{|c|}{ A549 } \\
\hline & Days $^{\mathbf{a}}$ & $G^{b}$ & Days & GD \\
\hline Control & 4.5 & & 5.5 & \\
\hline TZT-I 027 alone & 5.5 & 1 & 6.9 & 1.4 \\
\hline Radiation alone & 7.1 & 2.6 & 10.4 & 4.9 \\
\hline TZT-1027 + Radiation & 13.3 & 8.8 & 17.9 & 12.4 \\
\hline Enhancement factor & \multicolumn{2}{|c|}{3} & \multicolumn{2}{|c|}{2.2} \\
\hline
\end{tabular}

aDays, the period needed for the sizes of xenografts in each group to reach $500 \mathrm{~mm}^{3}$; ${ }^{\mathrm{b}} \mathrm{GD}$, the additional periods needed for the sizes of xenografts in each group to reach $500 \mathrm{~mm}^{3}$ in addition to the period needed for controls to reach $500 \mathrm{~mm}^{3}$.

2003), TZT-1027 might also be expected to affect tumour cells in interphase. With the use of synchronised tsFT210 cells, however, we found that TZT-1027 had no effect on progression of cells through the $G_{1}-S$ transition of the cell cycle. The effect of TZT1027 on cell cycle progression thus appears to be specific to $M$ phase.

Given that cells are most sensitive to radiation during mitosis (Sinclair and Morton, 1966; Sinclair, 1968; Pawlik and Keyomarsi,
Table 2 Body weight loss

\begin{tabular}{lcc}
\hline & \multicolumn{2}{c}{ \% of B.W. $\mathbf{L}^{\mathbf{a}}$} \\
\cline { 2 - 3 } & $\mathbf{H 4 6 0}$ & $\mathbf{A 5 4 9}$ \\
\hline Control & 3.6 & 1.2 \\
TZT- 1027 alone & 9.9 & 5.2 \\
Radiation alone & 9.7 & 5.5 \\
TZT- I 027+Radiation & 8.7 & 9.9 \\
\hline
\end{tabular}

a\% of B.W.L, relative body weight loss 7 days after the initiation of the treatment.

2004), we next investigated the possible interaction between TZT1027 and ionising radiation in human lung cancer cell lines. We found that TZT-1027 increased the sensitivity of H460 cells to $\gamma$ radiation in vitro. The proportion of $\mathrm{H} 460$ cells in mitotic phase at the time of irradiation was increased by TZT-1027 treatment, consistent with the notion that this effect contributes to the observed radiosensitisation induced by this drug. TZT-1027 was previously shown to induce apoptosis in several tumour cell lines (Watanabe et al, 2000). Although the relation between apoptosis and radiosensitivity is controversial (Lawrence et al, 2001; Pawlik and Keyomarsi, 2004), we showed that treatment of H460 cells with 


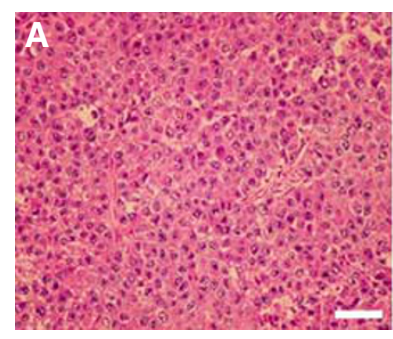

$\mathrm{Oh}$

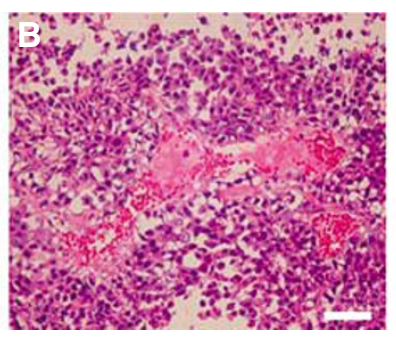

$4 \mathrm{~h}$

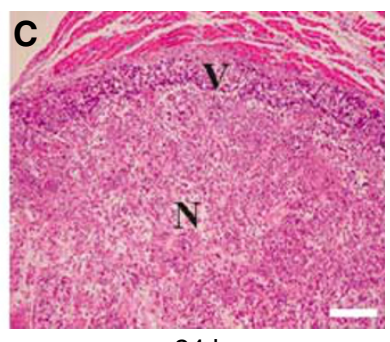

$24 \mathrm{~h}$

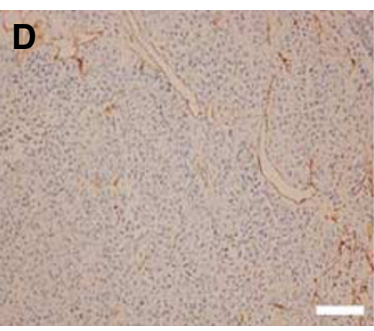

$\mathrm{Oh}$

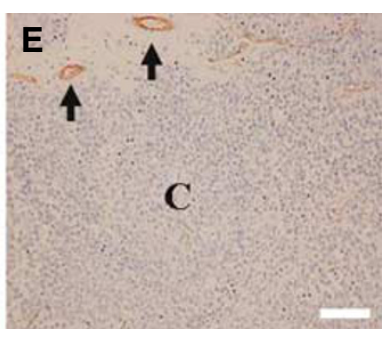

$4 \mathrm{~h}$

Figure 7 Histological analysis of $\mathrm{H} 460$ tumours after treatment with TZT- I 027. Mice bearing $\mathrm{H} 460$ tumour xenografts were treated with a single dose of TZT-I $027\left(2.0 \mathrm{mg} \mathrm{kg}^{-1}\right)$, and the tumours were excised at various times thereafter and either stained with hematoxylin-eosin $(\mathbf{A}-\mathbf{C})$ or immunostained for CD3I (D and E). (A and D) Control sections of an untreated tumour showing normal capillaries with an intact endothelium and viable tumour cells. (B and E) Sections of a tumour removed $4 \mathrm{~h}$ after administration of TZT- 1027. Vascular congestion, with pink deposits of fibrin, and loss of endothelial cells as well as diffuse tumour cell degeneration are apparent in (b). Dark immunostaining of intact endothelium (arrows) is apparent in surrounding normal connective tissue, whereas little staining of endothelial cells was observed in the core $(\mathbf{C})$ of the tumour $(\mathbf{E})$. (C) Section of a tumour removed $24 \mathrm{~h}$ after TZT- 1027 administration, showing extensive central necrosis ( $N$ ) and a rim of viable cells $(V)$. Scale bars: $50 \mu \mathrm{m}(\mathbf{A}$ and $\mathbf{B}), 100 \mu \mathrm{m}(\mathbf{C})$, and $200 \mu \mathrm{m}(\mathbf{D}$ and $\mathbf{E})$.

TZT-1027 before irradiation induced a marked increase in the proportion of apoptotic cells compared with that apparent with radiation alone. These results thus suggested that potentiation of apoptosis contributed to radiosensitisation by TZT-1027.

Combined treatment with radiation and a single administration of TZT-1027 also inhibited the growth of tumours formed by H460 or A549 cells in vivo to a greater extent than did either treatment alone. Tumour microenvironmental factors, such as the vascular supply, are important determinants of sensitivity to radiation therapy in vivo. The ability of microtubule-targeting agents to induce a rapid shutdown of the existing tumour vasculature has been recognised by their designation as vascular-targeting agents (VTAs) (Jordan and Wilson, 2004). Treatment with VTAs such as ZD6126 and combretastatin A-4-P typically results in the destruction of large areas of a tumour, with surviving cells remaining only at the tumour periphery (Dark et al, 1997; Blakey et $a l, 2002)$. These peripheral viable tumour cells presumably derive their nutritional support from nearby normal blood vessels that are not responsive to VTA treatment (Li et al, 1998; Siemann and Rojiani, 2002). Such support together with a rapid upregulation of angiogenic factors such as vascular endothelial growth factor may directly facilitate the growth and expansion of the remaining tumour cells (Wachsberger et al, 2003; Thorpe, 2004). Given that these residual tumour cells are likely well oxygenated (Wachsberger et al, 2003), they are an ideal target for radiation therapy. Several studies have recently shown that treatment with VTAs enhances the therapeutic effect of radiotherapy ( $\mathrm{Li}$ et al, 1998; Siemann and Rojiani, 2002, 2005; Horsman and Murata, 2003; Masunaga et al, 2004), consistent with the idea that the components of such combination therapy act in a complementary manner, with VTAs attacking the poorly oxygenated cell population in the central region of tumours and radiation killing the well-oxygenated proliferating cells at the tumour periphery (Li et al, 1998; Siemann and Rojiani, 2002; Wachsberger et al, 2003). TZT-1027 was previously shown to increase vascular permeability and to induce a decrease in tumour blood flow followed by a marked increase in tissue necrosis in the central region of tumour xenografts (Otani et al, 2000; Watanabe et al, 2006b). We have now shown that TZT-1027 treatment resulted in congestion and occlusion of tumour blood vessels followed by extensive necrosis of the tumour core, with only a thin rim of viable tumour cells remaining, in the $\mathrm{H} 460$ tumour model, suggesting that TZT-1027 acts as a VTA. The action of TZT-1027 as a VTA might thus contribute to the radiosensitising effect observed in vivo in the present study.

The clinical use of microtubule-interfering agents such as taxanes in combination with radiation has been successful in improving local tumour control. However, taxanes are often of limited efficacy because of the development of cellular resistance such as that mediated by P-glycoprotein-dependent drug efflux (Goodin et al, 2004). The action of TZT-1027 has been suggested to be less affected by multidrug resistance factors, including overexpression of P-glycoprotein, than that of other tubulin inhibitors (Watanabe et al, 2006a), suggesting that TZT-1027 may be effective in the treatment of taxane-refractory tumours. Further investigations are thus warranted to examine the combined effects of TZT-1027 and ionising radiation on drug-resistant tumour cells. Whether TZT-1027 enhances the tumour response to clinically relevant fractionated doses of radiation such as $2 \mathrm{~Gy}$ per fraction also warrants further study.

In conclusion, we have found that the inhibitory effect of TZT-1027 on cell cycle progression is highly specific to $M$ phase. Moreover, TZT-1027 enhanced the effects of radiation on human cancer cells both in vitro and in animal models in vivo. These preclinical results provide a rationale for future clinical investigations of the therapeutic efficacy of TZT-1027 in combination with radiotherapy.

\section{ACKNOWLEDGEMENTS}

We thank $\mathrm{H}$ Kakeya for providing tsFT210 cells as well as $\mathrm{M}$ Kobayashi, T Natsume, E Hatashita, Y Yamada, and S Ono for technical assistance. 


\section{REFERENCES}

Blakey DC, Westwood FR, Walker M, Hughes GD, Davis PD, Ashton SE, Ryan AJ (2002) Antitumor activity of the novel vascular targeting agent ZD6126 in a panel of tumor models. Clin Cancer Res 8: 1974-1983

Choy H, Yee L, Cole BF (1995) Combined-modality therapy for advanced non-small cell lung cancer: paclitaxel and thoracic irradiation. Semin Oncol 22: $38-44$

Dark GG, Hill SA, Prise VE, Tozer GM, Pettit GR, Chaplin DJ (1997) Combretastatin A-4, an agent that displays potent and selective toxicity toward tumor vasculature. Cancer Res 57: 1829-1834

de Jonge MJ, van der Gaast A, Planting AS, van Doorn L, Lems A, Boot I, Wanders J, Satomi M, Verweij J (2005) Phase I and pharmacokinetic study of the dolastatin 10 analogue TZT-1027, given on days 1 and 8 of a 3-week cycle in patients with advanced solid tumors. Clin Cancer Res 11: $3806-3813$

Edelstein MP, Wolfe III LA, Duch DS (1996) Potentiation of radiation therapy by vinorelbine (Navelbine) in non-small cell lung cancer. Semin Oncol 23: $41-47$

Goodin S, Kane MP, Rubin EH (2004) Epothilones: mechanism of action and biologic activity. J Clin Oncol 22: 2015-2025

Greystoke A, Blagden S, Thomas AL, Scott E, Attard G, Molife R, Vidal L, Pacey S, Sarkar D, Jenner A, De-Bono JS, Steward W (2006) A phase I study of intravenous TZT-1027 administered on day 1 and day 8 of a three-weekly cycle in combination with carboplatin given on day 1 alone in patients with advanced solid tumours. Ann Oncol 17: 1313-1319

Hofstetter B, Vuong V, Broggini-Tenzer A, Bodis S, Ciernik IF, Fabbro D, Wartmann M, Folkers G, Pruschy M (2005) Patupilone acts as radiosensitizing agent in multidrug-resistant cancer cells in vitro and in vivo. Clin Cancer Res 11: 1588-1596

Horsman MR, Murata R (2003) Vascular targeting effects of ZD6126 in a $\mathrm{C} 3 \mathrm{H}$ mouse mammary carcinoma and the enhancement of radiation response. Int J Radiat Oncol Biol Phys 57: 1047-1055

Jordan MA, Wilson L (2004) Microtubules as a target for anticancer drugs. Nat Rev Cancer 4: 253-265

Kim JC, Kim JS, Saha D, Cao Q, Shyr Y, Choy H (2003) Potential radiationsensitizing effect of semisynthetic epothilone B in human lung cancer cells. Radiother Oncol 68: $305-313$

Kim JS, Amorino GP, Pyo H, Cao Q, Price JO, Choy H (2001) The novel taxane analogs, BMS-184476 and BMS-188797, potentiate the effects of radiation therapy in vitro and in vivo against human lung cancer cells. Int J Radiat Oncol Biol Phys 51: 525-534

Kobayashi M, Natsume T, Tamaoki S, Watanabe J, Asano H, Mikami T, Miyasaka K, Miyazaki K, Gondo M, Sakakibara K, Tsukagoshi S (1997) Antitumor activity of TZT-1027, a novel dolastatin 10 derivative. Jpn J Cancer Res 88: $316-327$

Lawrence TS, Davis MA, Hough A, Rehemtulla A (2001) The role of apoptosis in $2^{\prime}, 2^{\prime}$-difluoro- $2^{\prime}$-deoxycytidine (gemcitabine)-mediated radiosensitization. Clin Cancer Res 7: $314-319$

Li L, Rojiani A, Siemann DW (1998) Targeting the tumor vasculature with combretastatin A-4 disodium phosphate: effects on radiation therapy. Int J Radiat Oncol Biol Phys 42: 899-903

Liebmann J, Cook JA, Fisher J, Teague D, Mitchell JB (1994) In vitro studies of Taxol as a radiation sensitizer in human tumor cells. J Natl Cancer Inst 86: $441-446$

Masunaga S, Sakurai Y, Suzuki M, Nagata K, Maruhashi A, Kinash Y, Ono $\mathrm{K}$ (2004) Combination of the vascular targeting agent ZD6126 with boron neutron capture therapy. Int J Radiat Oncol Biol Phys 60: 920-927

Miyazaki K, Kobayashi M, Natsume T, Gondo M, Mikami T, Sakakibara K, Tsukagoshi S (1995) Synthesis and antitumor activity of novel dolastatin 10 analogs. Chem Pharm Bull (Tokyo) 43: $1706-1718$

Mollinedo F, Gajate C (2003) Microtubules, microtubule-interfering agents and apoptosis. Apoptosis 8: $413-450$

Natsume T, Watanabe J, Horiuchi T, Kobayashi M (2006) Combination effect of TZT-1027 (Soblidotin) with other anticancer drugs. Anticancer Res 26: $1145-1151$

Natsume T, Watanabe J, Koh Y, Fujio N, Ohe Y, Horiuchi T, Saijo N, Nishio K, Kobayashi M (2003) Antitumor activity of TZT-1027 (Soblidotin) against vascular endothelial growth factor-secreting human lung cancer in vivo. Cancer Sci 94: 826-833

Natsume T, Watanabe J, Tamaoki S, Fujio N, Miyasaka K, Kobayashi M (2000) Characterization of the interaction of TZT-1027, a potent antitumor agent, with tubulin. Jpn J Cancer Res 91: 737-747

Osada H, Cui CB, Onose R, Hanaoka F (1997) Screening of cell cycle inhibitors from microbial metabolites by a bioassay using a mouse cdc2 mutant cell line, tsFT210. Bioorg Med Chem 5: 193-203

Otani M, Natsume T, Watanabe JI, Kobayashi M, Murakoshi M, Mikami T, Nakayama T (2000) TZT-1027, an antimicrotubule agent, attacks tumor vasculature and induces tumor cell death. Ipn I Cancer Res 91: 837-844

Pawlik TM, Keyomarsi K (2004) Role of cell cycle in mediating sensitivity to radiotherapy. Int J Radiat Oncol Biol Phys 59: 928-942

Schoffski P, Thate B, Beutel G, Bolte O, Otto D, Hofmann M, Ganser A, Jenner A, Cheverton P, Wanders J, Oguma T, Atsumi R, Satomi M (2004) Phase I and pharmacokinetic study of TZT-1027, a novel synthetic dolastatin 10 derivative, administered as a 1-hour intravenous infusion every 3 weeks in patients with advanced refractory cancer. Ann Oncol 15: $671-679$

Siemann DW, Rojiani AM (2002) Enhancement of radiation therapy by the novel vascular targeting agent ZD6126. Int J Radiat Oncol Biol Phys 53: $164-171$

Siemann DW, Rojiani AM (2005) The vascular disrupting agent ZD6126 shows increased antitumor efficacy and enhanced radiation response in large, advanced tumors. Int J Radiat Oncol Biol Phys 62: $846-853$

Simoens C, Vermorken JB, Korst AE, Pauwels B, De Pooter CM, Pattyn GG, Lambrechts HA, Breillout F, Lardon F (2006) Cell cycle effects of vinflunine, the most recent promising Vinca alkaloid, and its interaction with radiation, in vitro. Cancer Chemother Pharmacol 58: 210-218

Sinclair WK (1968) Cyclic x-ray responses in mammalian cells in vitro. Radiat Res 33: 620-643

Sinclair WK, Morton RA (1966) X-ray sensitivity during the cell generation cycle of cultured Chinese hamster cells. Radiat Res 29: 450-474

Tamura K, Nakagawa K, Kurata T, Satoh T, Nogami T, Takeda K, Mitsuoka S, Yoshimura N, Kudoh S, Negoro S, Fukuoka M (2007) Phase I study of TZT-1027, a novel synthetic dolastatin 10 derivative and inhibitor of tubulin polymerization, which was administered to patients with advanced solid tumors on days 1 and 8 in 3-week courses. Cancer Chemother Pharmacol (in press)

Tamura K, Rice RL, Wipf P, Lazo JS (1999) Dual $G_{1}$ and $G_{2} / M$ phase inhibition by SC-alpha alpha delta 9, a combinatorially derived Cdc25 phosphatase inhibitor. Oncogene 18: 6989-6996

Thorpe PE (2004) Vascular targeting agents as cancer therapeutics. Clin Cancer Res 10: $415-427$

Vokes EE, Haraf DJ, Masters GA, Hoffman PC, Drinkard LC, Ferguson M, Olak J, Watson S, Golomb HM (1996) Vinorelbine (Navelbine), cisplatin, and concomitant radiation therapy for advanced malignancies of the chest: a Phase I study. Semin Oncol 23: 48-52

Wachsberger P, Burd R, Dicker AP (2003) Tumor response to ionizing radiation combined with antiangiogenesis or vascular targeting agents: exploring mechanisms of interaction. Clin Cancer Res 9: 1957-1971

Watanabe J, Minami M, Kobayashi M, Natsume T, Watanabe J, Horiuchi T, Kobayashi M (2006a) Antitumor activity of TZT-1027 (Soblidotin). Anticancer Res 26: $1973-1981$

Watanabe J, Natsume T, Fujio N, Miyasaka K, Kobayashi M (2000) Induction of apoptosis in human cancer cells by TZT-1027, an antimicrotubule agent. Apoptosis 5: 345-353

Watanabe J, Natsume T, Kobayashi M (2006b) Antivascular effects of TZT1027 (Soblidotin) on murine Colon26 adenocarcinoma. Cancer Sci 97: $1410-1416$

Workman P, Twentyman P, Balkwill F, Balmain A, Chaplin D, Double J, Embleton J, Newell D, Raymond R, Stables J, Stephens T, Wallace J (1998) United Kingdom Co-ordinating Committee on Cancer Research (UKCCCR) Guidelines for the Welfare of Animals in Experimental Neoplasia 2nd edn. Br J Cancer 77: 1 - 10 